\title{
From Pioneer Days \\ to the Dawn of Industrial Relations: The Emergence of the Working Class in Dubuque, 1833-1855
}

\author{
RALPH SCHARNAU
}

DURING THE PERIOD between the Civil War and the First World War, the United States became an economic superpower. But it was the antebellum era that laid the groundwork for that development. General textbook surveys of U.S. history label the period from 1815 to 1860 as one of striking economic transformation. Evidence of the changing times came with growth in the ranks of wage earners, a rapid increase of urbanization, the rise of factory production, the spread of market activity, and advances in technology, communication, and transportation. Although the changes were far from complete, the first stage of the nation's economic revolution had clearly arrived by the middle of the nineteenth century. ${ }^{1}$

These great economic and social transformations are often expressed in the term industrialization. ${ }^{2}$ The forces of industrialism started in the East, then rolled westward across the Mississippi River, and by 1850 reached as far west as the Great Plains.

1. See, for example, Alan Brinkley, American History: A Survey (New York, 2007), chap. 10; and Irwin Unger, These United States: The Questions of Our Past, vol. 1, 3rd concise ed. (Upper Saddle River, NJ, 2007), chap. 9.

2. Walter Licht, Industrializing America: The Nineteenth Century (Baltimore, 1995). See also Ruth L. Hoadley, Industrial Growth of Iowa (Iowa City, 1928).

THE ANNALS OF IOWA 70 (Summer 2011). (C) The State Historical Society of Iowa, 2011. 
Built on a rapidly expanding population, the new economic structure was knit together by rail and water and the beginnings of modern business management. ${ }^{3}$ Throughout the nineteenth century, the American Midwest experienced both industrial and agricultural development. The sustained and simultaneous growth of farm and factory created two contrasting and largely separate work forces. Organized labor emerged as a distinct and formidable presence in midwestern industry. ${ }^{4}$

The decade from 1845 to 1855 witnessed enormous change for the Mississippi River town of Dubuque, Iowa. The rapid settlement and economic growth of this period between the panics of 1837 and 1857 changed the face of the community from a sleepy little mining village to the premier commercial center between St. Paul and St. Louis. By 1855, the city's harbor facilities teemed with passenger and freight steamers, and the newly laid Illinois Central Railroad tracks reached Dunleith (presentday East Dubuque) on the Illinois side of the river. Small-scale manufacturing enterprises, relying mostly on human, horse, or water power, processed raw materials from forests, mines, and fields. A burgeoning labor force kept pace with the economic transformation. Independent minded and hard working, Dubuque's pre-Civil War workers provided the labor force that shaped the town's material culture and public image. ${ }^{5}$

Traditionally, histories of Mississippi River towns like Dubuque meant accounts of early pioneers, civic happenings, entrepreneurs, and business transactions. ${ }^{6}$ Such towns followed similar paths of economic development based on commerce and artisan production. ${ }^{7}$ A recent study explored the role of

3. Thomas C. Cochran, 200 Years of American Business (New York, 1977), chap. 4.

4. Daniel Nelson, Farm and Factory: Workers in the Midwest, 1880-1990 (Bloomington, IN, 1995), vii-viii.

5. For general accounts of the city, see Franklin T. Oldt, History of Dubuque County, Iowa (Chicago, 1911); [Chandler C. Childs], History of Dubuque County (Chicago, 1880); William E. Wilkie, Dubuque on the Mississippi, 1788-1988 (Dubuque, 1987); and Randolph W. Lyon, Dubuque: The Encyclopedia (Dubuque, 1991). For an overview of Dubuque labor, see Ralph Scharnau, "Workers, Unions, and Workplaces in Dubuque, 1830-1990," Annals of Iowa 52 (1993), 50-78.

6. See the sources cited in n. 5.

7. Edwin B. Espenshade Jr., "Urban Development at the Upper Rapids of the Mississippi" (Ph.D. diss., University of Chicago, 1944); Timothy R. Mahoney, 
Dubuque's early booster elite in the changing economic structure of the community during the 1850 s. ${ }^{8}$ Early entrepreneurs in Jacksonville, Illinois, and the Twin Cities played a similar role in developing businesses that produced commodities for trade and commerce. ${ }^{9}$

This study, by contrast, focuses on Dubuque's labor history. The years from 1845 to 1855 were prosperous times. During that decade, first mining and then lumbering supplied the foundation of the city's status as a commercial center, created personal fortunes, provided an occupation for many, and capitalized future industrial development. The emphasis here is on wage earners and their workplace conditions and living standards.

Compared to the rest of the state, Dubuque was a distinctive place in the pre-Civil War years. Iowa's oldest community differed by virtue of its hilly terrain and lead mines as well as a citizenry largely devoted to Catholicism in religion and the Democratic Party in politics. The origins of Dubuque's reputation as an industrial city with a large working-class population and sturdy unions can be traced to the era that preceded the Civil War.

FOR A DOZEN YEARS following its founding in 1833, Dubuque bore the markings of a rough frontier mining community. The first bank was aptly named Miners Bank, and the Miners' Express functioned as the newspaper of record. The Panic of 1837 ushered in six years when emigration slowed, the price of lead dropped, and business generally dulled. Although the population probably reached 3,000 to 3,500 by 1845 , the city itself consisted of a few dirt streets and small clusters of crudely built log and frame dwellings, stores, and shops with a smat-

River Towns in the Great West: The Structure of Provincial Urbanization in the American Midwest, 1820-1870 (New York, 1990).

8. Timothy R. Mahoney, "The Rise and Fall of the Booster Ethos in Dubuque, 1850-1861," Annals of Iowa 61 (2002), 371-419.

9. Don Harrison Doyle, The Social Order of a Frontier Community: Jacksonville, Illinois, 1825-1870 (Urbana, IL, 1978); Jocelyn Wills, Boosters, Hustlers, and Speculators: Entrepreneurial Culture and the Rise of Minneapolis and St. Paul, 1849-1883 (St. Paul, MN, 2005).

10. Scharnau, "Workers, Unions, and Workplaces." 


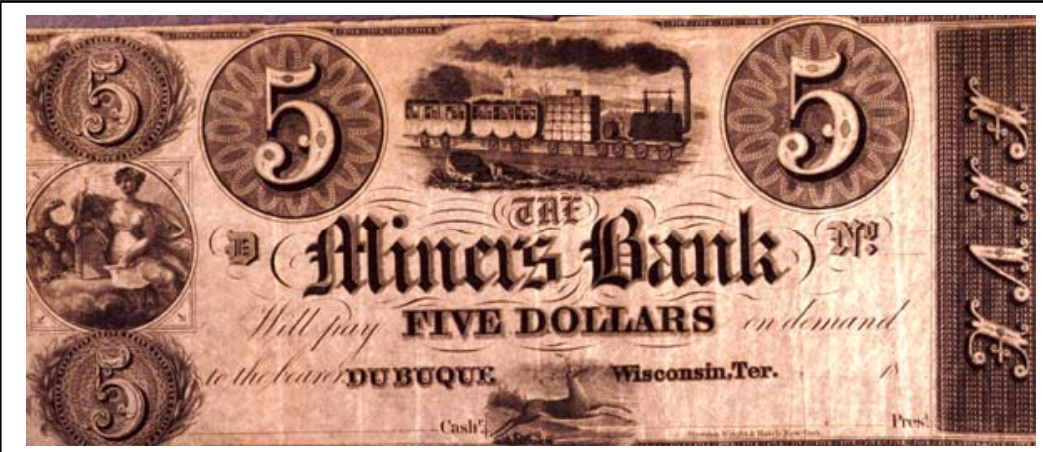

Dubuque's first bank, the Miners Bank, opened in 1833 with a capital investment of $\$ 100,000$. Courtesy Dubuque County Historical Society.

tering of modest churches and schools. Less than 10 percent of the land in Dubuque County had been sold. Besides a large number of miners, the work force included craftsmen and laborers. Production of manufactured goods remained exclusively a home-based and small shop affair. ${ }^{11}$

From the beginning, then, the city's reputation and prosperity rested on lead mining. Officially opened to settlement by Europeans in 1833, Dubuque was named after the French Canadian lead miner Julien Dubuque. ${ }^{12}$ On June 1, 1833, "several hundred miners poured into the Dubuque area." According to Tacie Campbell, curator at the Dubuque County Historical Society,

11. John B. Newhall, A Glimpse of Iowa in 1846 or the Emigrant's Guide and State Directory, 2nd ed. (Burlington, 1846), 72; Josiah Conzett, Recollections of People and Events: Dubuque, Iowa, 1846-1890 (Dubuque, 1971), 274; Federal Writers' Project of WPA, "A New History of Dubuque County," Dubuque Telegraph Herald, 12/25/1938; Wilkie, Dubuque on the Mississippi, 143, 152, 157; Oldt, History of Dubuque County, 20-22, 48, 55, 70; Childs, History of Dubuque County, 459-73; Ralph Scharnau, "The Business and Industrial History of Dubuque, 1833-1900," in Russell W. Nash, comp., Dubuque Beginnings (Dubuque, 1985), 30; Iowa News, 6/24/1837. The Du Buque Visitor and the Iowa News preceded publication of the Miners' Express, which began publication on August 1, 1841. See David C. Mott, "Early Iowa Newspapers," Annals of Iowa 16 (1928), 177. All newspapers cited in this study were published in Dubuque. The frequency of publication varied from daily to weekly, so these designations in the newspaper mastheads have been eliminated in the citations.

12. Wilkie, Dubuque on the Mississippi, chap. 3; Oldt, History of Dubuque County, 19-20, 43 . 
"this was the first real mining rush in the history of the United States." ${ }^{13}$ Subsequently, lead drew thousands of would-be miners to the area. Getting started in lead mining required a permit or a lease, a small financial outlay, and simple tools. Many of the earliest all-male coteries of laborers worked in the area lead mines and lived in log cabins. Lucius Langworthy, a prominent mine owner, banker, and land speculator, placed the Dubuque population at 700 to 800 in 1836. In that same year, five blast furnaces smelted the lead ore. ${ }^{14}$

According to historian Tom Auge, mining and the river captured the essence of early Dubuque. Miners found lead in surface crevices that led to further deposits below ground. Eventually the area's hilly terrain became laced with surface, cave, and shaft mines. The lead was smelted into pigs or bars and then carried via steamboat to St. Louis, where it was processed for shot, pipe, and paint. Every year riverboats carried millions of pounds of lead ore that brought payments of hundreds of thousands of dollars. The city's first capitalists enriched themselves on the mineral and built mansions.

Lead mining brought fortunes to a few and employment to many. Dubuque area lead miners worked under challenging conditions. The typical miner worked 10 to 12 hours per day, six days per week, and 52 weeks per year. Injury, disease, and even death awaited some miners. The mine laborer used hand-operated devices, carts and buckets, picks, shovels, sledge hammers, and windlasses. Chipping and hauling lead ore all day made miners bone-weary. Working in cave or, more commonly, shaft mines meant using tallow candles tacked to the wall for light and en-

13. Loren Nelson Horton, "Town Planning, Growth, and Architecture in Selected Mississippi River Towns of Iowa, 1833-1860" (Ph.D. diss., University of Iowa, 1978), 47; Rich Kirchen, "This Land Is Mine Land, This Land Is Ore Land," Telegraph Herald, Insight Section, 2/23/1988 (Campbell quote).

14. Wilkie, Dubuque on the Mississippi, 143; Lucius H. Langworthy, Dubuque: Its History, Mines, Indian Legends, Etc. (Dubuque, 1855), 26, 29, 46 (Langworthy's treatise is reprinted in the Iowa Journal of History and Politics 8 [1910], 366-422).

15. Thomas Auge, "Historical Survey of Dubuque Mining," n.d., typescript, Center for Dubuque History, Loras College, Dubuque, Iowa, 4-7; Kirchen, "This Land"; WPA Writers' Project, "A New History of Dubuque County," 24; Jacob Swisher, "Mining in Iowa," Iowa Journal of History and Politics 43 (1945), 310-11; Oldt, History of Dubuque County, 23; Wilkie, Dubuque on the Mississippi, 143; Express and Herald, 11/27/1855. 


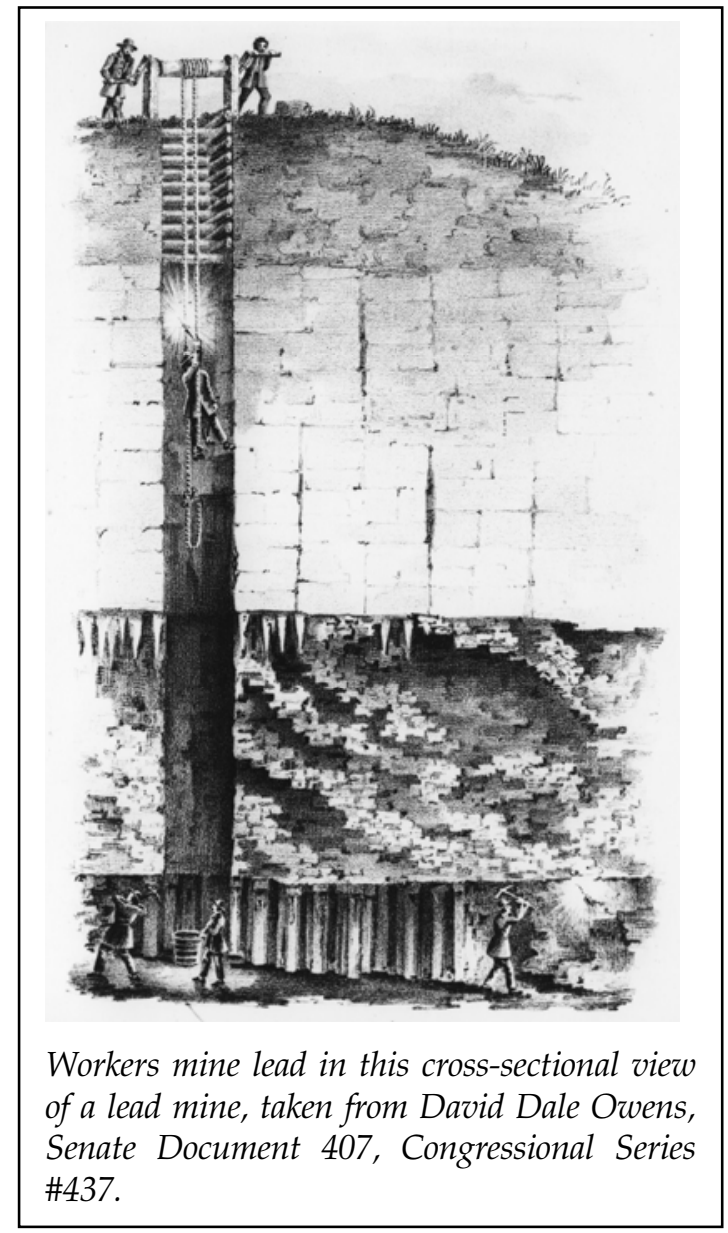

during the steady dripping of water on and around the miners. The work, moreover, could be extremely dangerous when flooding and cave-ins occurred. Gas and ventilation issues also posed threats. Unskilled miners' earnings averaged only about one dollar per day. ${ }^{16}$

16. Jack Brimeyer and John McCormick, Our Early Years (Dubuque, 1976), 40, 43; Oldt, History of Dubuque County, 22, 25; Childs, History of Dubuque County, 468; Wilkie, Dubuque on the Mississippi, 143, 144; Richard D. Cuthbertsen, "The History of Lead Mining in the Dubuque Area" (M.A. thesis, Drake University, 1957), 39-40; Loren Farrey, A Tour Guide to the Mines of Lafayette County, Wiscon$\sin$ (Mineral Point, WI, 2001), 48. 


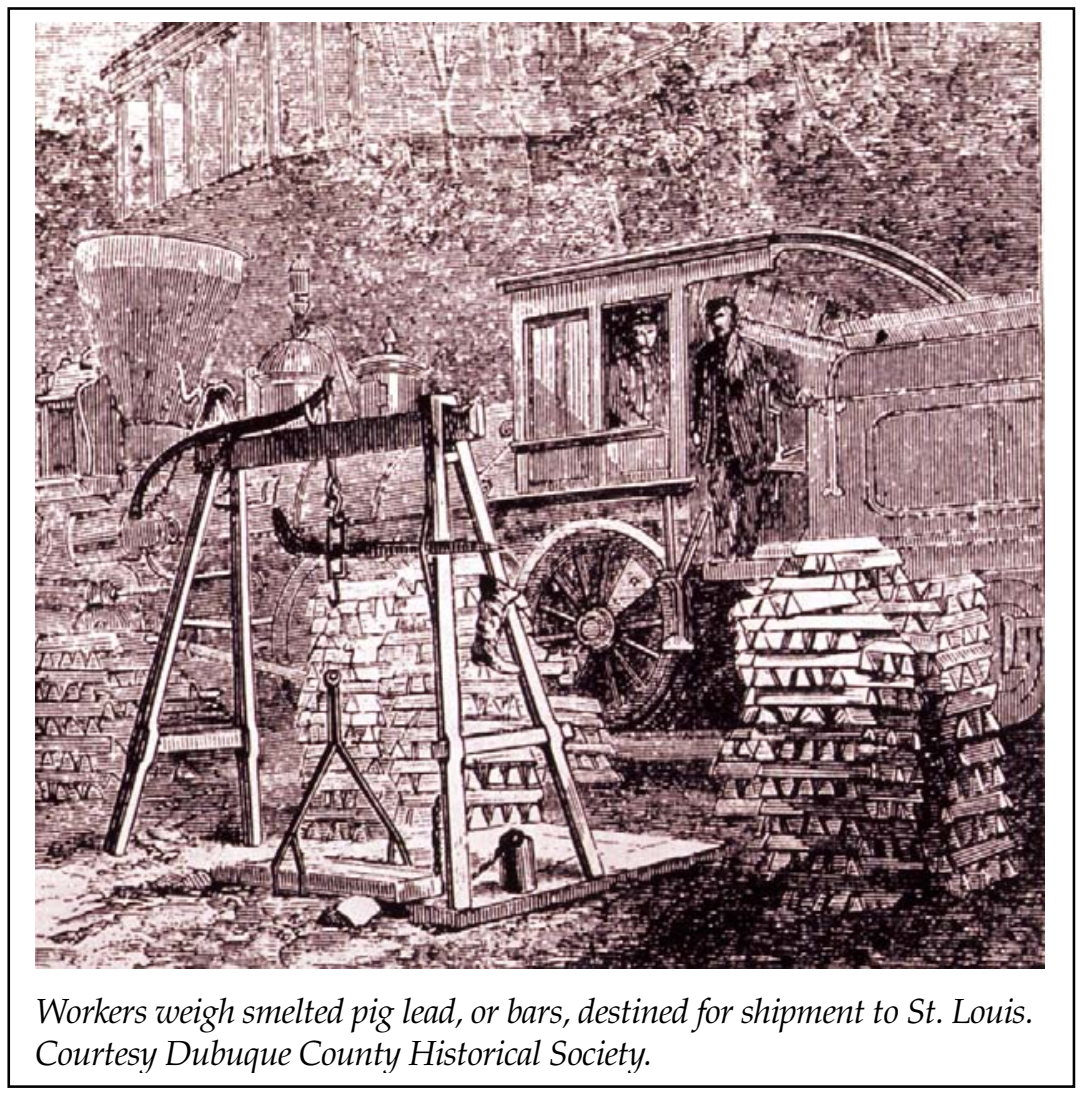

After miners dug the ore, smelters converted it into a commercial asset. Output increased with the introduction of improved furnaces. Smelter workers faced hot, exhausting, and perilous working conditions. The smelting process used logs to stoke the furnaces. Releasing the lead from the ore required 621degree heat. The smelting furnaces spewed thick smoke into the air and unleashed sulfurous gas that invaded and poisoned workers' lungs. The lead ore was smelted into 70-pound pigs that were stacked by hand on site. In 1850 each of seven lead smelting operations employed four to ten workers earning average wages of $\$ 24$ per month. ${ }^{17}$

17. Wilkie, Dubuque on the Mississippi, 143-44; Oldt, History of Dubuque County, 21; Brimeyer and McCormick, Our Early Years, 29, 40, 42-43; U.S. Census, Products of Industry, 1850. 
The years from 1835 to 1849 marked the golden age of lead mining in Dubuque. One commentator estimated that half of the city's townsmen engaged in mining in 1846. During peak production periods in the 1840s, the number of miners in Dubuque County and the surrounding area reached, at times, an astonishing high of 3,000 men covering an area 50 miles north and south and 20 miles east and west of Dubuque. An estimated 90 percent of the nation's lead supply and 10 percent of the world's came from the upper Mississippi River lead region. ${ }^{18}$

Beginning in 1849 , the industry gradually declined as miners migrated out of the area because of depleted lead deposits and the lure of California gold. By 1855, a resident observer placed the number of Dubuque miners at "some 300." Although the quantity of lead diminished and the value fluctuated, new discoveries and occasional large profits kept the enterprise going into the post-Civil War era. ${ }^{19}$

AS LEAD MINING WANED, wood products became Dubuque's principal industry. A boom in the lumber business began in the mid-1840s. A decade later, sawmills, lumberyards, planing mills, and sash-and-door factories employed more Dubuque workers than any other industry and generated huge fortunes. Wood became the new symbol of Dubuque's prosperity. The city's Mississippi River shoreline offered physical evidence of the important role of lumber in the city's economic life. ${ }^{20}$

Dubuque's first European settlers cut local timber for cabins, fuel, and fences. Pioneer woodworkers put in long hours using a variety of hand tools: axes, saws, froes, adzes, drawknives, augers, chisels, and planes. Output in the woodworking

18. Childs, History of Dubuque County, 463; William J. Petersen, "Beginnings of Dubuque: The El Dorado of Iowa," Palimpsest 21 (1940), 350; Conzett, Recollections of People and Events, 275; Oldt, History of Dubuque County, 21-24; Kirchen, "This Land," 17.

19. G. R. West, Statistics of the City of Dubuque (Dubuque, 1856), 14; Childs, History of Dubuque County, 527, 528; Brimeyer and McCormick, Our Early Years, 45, 47; Dubuque Tribune, 3/30/1849, 5/18/1849, 10/16/1850; Miners' Express, 4/17/1849, 4/24/1849; Dubuque Republican, 8/21/1857; Oldt, History of Dubuque County, 24-30, 84, 87; Kirchen, "This Land."

20. Scharnau, "Business and Industrial History," 31. 
industry increased steadily in the pre-Civil War years. By 1855, Dubuque had already moved through three overlapping stages: sawmilling, rafting, and planing. ${ }^{21}$

The county's first sawmill was run by water power. Commencing such operations required common laborers, carpenters, and wheelwrights to construct dams, water wheels, and sawmill buildings. Production expanded when a local steampowered sawmill was erected as early as 1837. Sawing efficiency increased with the introduction of the double-edge saw about 1850. In 1854 a shingle machine at a local sawmill cut pine, walnut, chestnut, oak, and ash at the rate of 2,000 to 3,000 pieces per hour. ${ }^{22}$

Increasing construction and fuel uses accounted for the exhaustion of local timber supplies by the late 1840s. Thereafter, lumbermen assailed the vast pine forests of Wisconsin and Minnesota. Mississippi River rafting became an economical way of moving lumber and logs from the northern pineries to river towns like Dubuque. The floating raft period encompassed the years from the 1830s to the Civil War. ${ }^{23}$

"Booming" (floating wood to mills) required a work force with considerable skills. Workers considered rafting a hard life but one filled with exciting adventures and boisterous camaraderie. The rafts measured several hundred feet in length and traveled at a rate of about two miles per hour. Equipped with low shacks and a cook's shanty, the rafts became small communities for the 20 to 25 crewmen who lived on them. ${ }^{24}$

21. Floyd B. Haworth, The Economic Development of the Woodworking Industry in Iowa (Iowa City, 1933), 8-9, 12-15. See also Lyda Belthuis, "The Lumber Industry in Eastern Iowa," Iowa Journal of History and Politics 46 (1948), 115, 119; George Bernhardt Hartman, "The Iowa Sawmill Industry," Iowa Journal of History and Politics 40 (1942), 58; A. A. Cooper Autobiography, 14-page typescript, Center for Dubuque History, Loras College, Dubuque, 6-7.

22. Dubuque Observer, 11/3/1854; Haworth, Development of the Woodworking Industry, 15-19, 30; Belthuis, "Lumber Industry in Eastern Iowa," 125; Hartman, "Iowa Sawmill Industry," 57, 59; Wilkie, Dubuque on the Mississippi, 151.

23. William J. Petersen, "Rafting on the Mississippi: Prologue to Prosperity," Iowa Journal of History 58 (1960), 285, 292, 300; Wilkie, Dubuque on the Mississippi, 151; Belthuis, "Lumber Industry in Eastern Iowa," 126.

24. Haworth, Development of the Woodworking Industry, 21; Belthuis, "Lumber Industry in Eastern Iowa," 126; Petersen, "Rafting on the Mississippi," 308-11. 


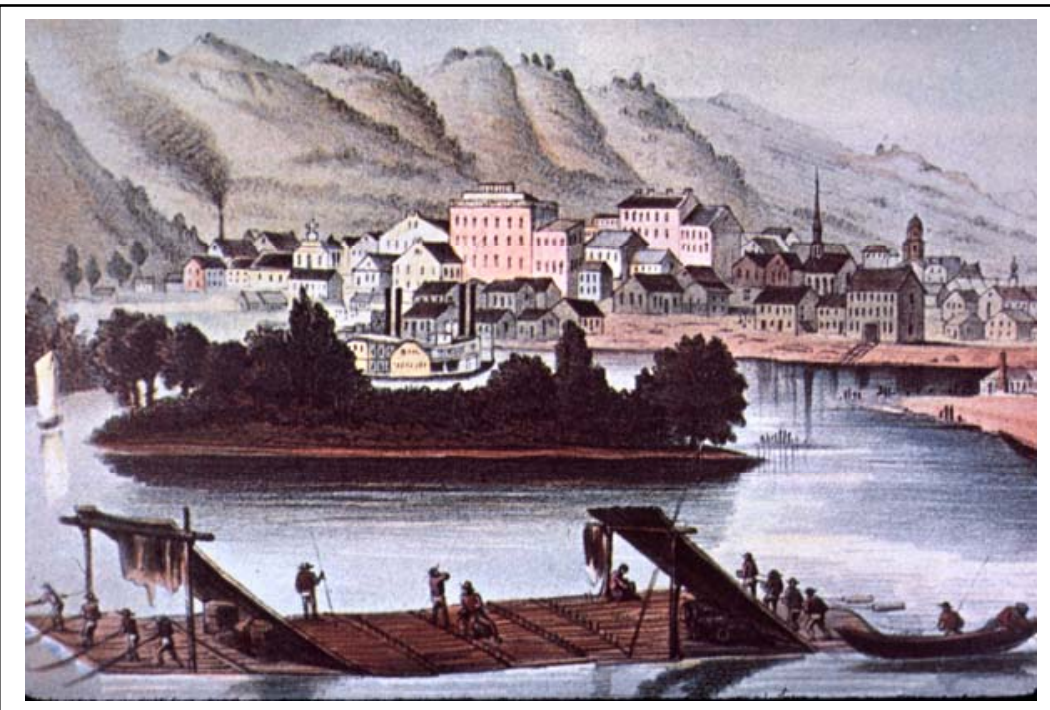

Workers enter the port of Dubuque on a log raft. Courtesy Dubuque County Historical Society.

According to the 1850 census, woodworking, as a manufacturing category, accounted for a third of Dubuque County's industrial sites. The work forces varied from one to six at each of the six sawmills, five cooperages, two wagon makers, one wheelwright, and one cabinetmaker. Wage levels for these employees averaged $\$ 25$ per month. ${ }^{25}$

As large numbers of newcomers entered the city in the mid1850s, a great demand arose for skilled construction workers. The Miners' Express encouraged brick makers, bricklayers, and carpenters to settle in Dubuque. City statistics count 333 new buildings erected in 1854 and 471 in 1855, with a continuing need for more building tradesmen. In addition to the construction of houses, stores, and other buildings, small shops with a few skilled workers made furniture and cooperage. ${ }^{26}$

25. U.S. Census, Iowa, Products of Industry, 1850.

26. Miners' Express, 8/9/1853; West, Statistics, 7, 8. See also G. R. West, “Commerce of Dubuque, Iowa," Western Journal and Civilian (1855), 140, 141; and the Dubuque City Directory, 1856. 
The scale of the woodworking industry advanced significantly with the introduction of steam planing machines in 1850. The steam planing machine featured the new circular saw. Lathes and boring machines added another technological dimension to wood processing. The planing mills manufactured sash, doors, window and door frames, moldings, and interior woodwork. With their mass production of wood construction products, these planing mills became Dubuque's first real industrial plants. These factories required highly skilled work forces. Compared to other manufacturing establishments, the planing mills were large operations, each employing 15 to 35 men. Owners of sawmills in towns along the Mississippi River amassed huge fortunes. ${ }^{27}$

Sawmills, lumber and log rafts, artisan shops, and planing mills each represented not only the economic development of an industry but also a subdivision of labor. Machine technology began to replace the hand tools of the individual wood craftsmen. Specialization of task became the hallmark of an industry moving toward mass production. By 1855, then, Dubuque had evolved through the "cabin, cottage, shop, and factory" stages of the wood products industry. ${ }^{28}$

MINING AND LUMBERING, as the twin pillars of Dubuque's economic growth, provide a context for the physical, economic, and social transformation of the city. The years from 1845 to 1855 marked a dramatic break with the pioneer period. These years brought rapid population growth accompanied by expanded business activity, increased mechanization, and enlarged labor forces. Public expenditures and improvements on the Dubuque riverfront brought booming human and cargo traffic. The heavy flow of immigrants resulted in the designation of the city as a

27. Haworth, Development of the Woodworking Industry, 41, 49; Dubuque Tribune, 11/13/1850, 7/25/1851; Miners' Express, 10/10-13/1854; Express and Herald, 6/27/1856; John Edward Westburg, "The Classless Society of Pioneer Iowa, 1830-1860," North American Mentor Magazine 25 (Summer 1987), 15-16 (Westburg's pre-Civil War sketch of the Iowa working class is a reprint of 25 articles that appeared in the Des Moines Federationist, a weekly labor paper, between November 16, 1939, and May 16, 1940).

28. Haworth, Development of the Woodworking Industry, 68. 


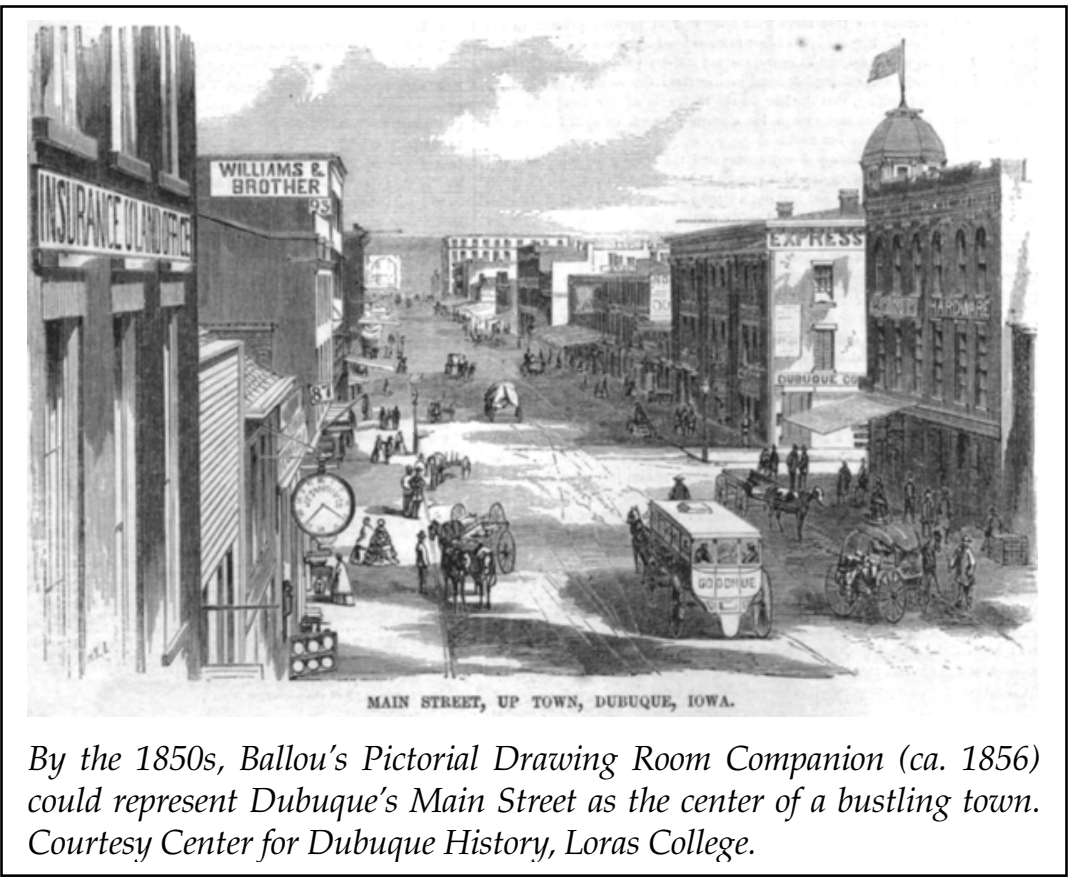

"port of entry" to the United States and the stationing of immigration officials. ${ }^{29}$

Beginning in the summer of 1845 , a local observer noted, immigrants became less "transient" as more and more people "identified themselves with the city and surrounding country." After reaching 3,106 inhabitants in 1850, the population doubled in just four years, and two years later, in 1856, the census nearly doubled again to 11,780 . Dubuque's newspapers reported the almost "daily - yes, hourly" arrival of a "countless throng of immigrants." ${ }^{30}$

The arrival of newcomers and expansion of economic activities fueled investment in land agencies. Dubuquer Horatio W. Sanford became "Iowa's largest land speculator and one of the

29. William Roba, "Ride the River Back in Time," Telegraph Herald, 2/23/1988; WPA Writers' Project, "A New History of Dubuque County," foreword, 11.

30. Childs, History of Dubuque County, 524; John A. T. Hull, Census of Iowa for 1880 (Des Moines, 1883), 474; Iowa Census, 1856; WPA Writers' Project, "A New History of Dubuque County," 11; N. Howe Parker, Iowa As It Is in 1855 (Chicago, 1855), 55 (newspaper quotes). 
state's first realtors and moneylenders." ${ }^{\prime 1}$ The local press acclaimed the flurry of land sales.

The growth of manufacturing enterprises accompanied the real estate developments. The new establishments included steam-powered flour- and sawmills, breweries, wagon shops, iron works, furniture makers, foundries, and machine shops. ${ }^{32}$

The economic boosterism included breathlessly citing a litany of city improvements: the telegraph, gas lighting, and a macadamized Main Street as well as new brick buildings, improved railroad connections, and increased steamboat traffic. Paralleling these developments, the number of "various mechanics" jumped from roughly 1,520 in 1854 to 2,010 in 1855 . Although local production in artisan shops remained primary, the city had lost its mining camp image and become a compact urban center, a regional commercial hub, and a river and railroad trade nexus. ${ }^{34}$

DUBUQUE'S WORKING CLASS - common laborers, artisans, and servants - was the foundation for the town's new prosperity. Exuding optimism and opportunity, an 1846 emigrant guide appealed to potential newcomers by touting the Dubuque area as a well-timbered region with rich agricultural

31. Robert P. Swierenga, Pioneers and Profits: Land Speculation on the Iowa Frontier (Ames, 1968), 112; Wilkie, Dubuque on the Mississippi, 160-62.

32. Miners' Express, 12/19/1849, 8/11/1852, 4/12/1852, 7/29/1853, 5/30/1854, 10/10-13/1854; Dubuque Tribune, 8/31/1849, 11/13/1850, 7/25/1851; Express and Herald, 5/2/1855, 1/1/1856, 1/17/1856, 6/27/1856; Childs, History of Dubuque County, 647-67; Oldt, History of Dubuque County, 85-86, 94-95; Russell Lee Johnson, "An Army for Industrialization: The Civil War and the Formation of Urban-Industrial Society in a Northern City" (Ph.D. diss., University of Iowa, 1996), 70-71.

33. Dubuque Tribune, $10 / 25 / 1847,5 / 12 / 1848,8 / 31 / 1849,11 / 13 / 1850$; Miners' Express, 4/7/1852, 4/14/1852, 8/11/1852, 4/12/1853, 7/29/1853, 3/14/1854, 5/30/1854, 10/18/1854, 10/19/1854, 10/24/1854; Express and Herald, 5/2/1855, 6/2/1855, 1/1/1856, 1/17/1856; Childs, History of Dubuque County, 524-27, 530-31; West, "Commerce," 137-43; West, Statistics, 15; Johnson, "An Army for Industrialization," 71-72.

34. Wilkie, Dubuque on the Mississippi, 152, 185; Brimeyer and McCormick, Our Early Years, 48; Miners' Express, 8/30/1954; James E. Jacobsen, Dubuque, the Key City: Architectural and Historical Resources of Dubuque, Iowa, 1837-1955 (Des Moines, 2002), 19; Johnson, "An Army for Industrialization," 29, 51. 
soil and plentiful lead deposits. Mechanics and laborers who settled in the town of Dubuque could expect, according to the guide, "a certainty of employment and fair wages." The wages of day laborers varied from 75 cents to a dollar per day while stonecutters and bricklayers earned from $\$ 1.25$ to $\$ 2.00$ per day. "Respectable board and lodging" costs ranged from \$1.50 to $\$ 2.00$ per week. ${ }^{35}$

The federal census of 1850 and the state census of 1856 provide a demographic profile of the city's wage earners. They were a youthful lot, mostly unmarried males in their late teens, twenties, and thirties. Migrants to Dubuque came from New England, the Middle Atlantic region, the surrounding states of Illinois, Missouri, and Wisconsin, and the South. In 1850 the foreign-born accounted for a majority of the local population. The bulk of the immigrants hailed from Ireland ( 25 percent) and Germany (18 percent). Other residents came from England, Switzerland, Prussia, Canada, France, Luxembourg, Austria, Wales, Scotland, Italy, and Scandinavia, but those with Irish and German ancestry, native and foreign-born, clearly dominated the 1850 and 1856 census rolls. ${ }^{36}$

The concentration of Irish people in the southern part of Dubuque earned that section of town the nickname "Dublin." The mostly unskilled Irish laborers came from peasant backgrounds. Many took jobs as day laborers; others secured employment as miners or in the building trades. Still others worked in transportation as teamsters, draymen, or boatmen. A few males held jobs as professionals, and most women worked as domestics. The poor laborers often lived in frame shanties. ${ }^{37}$

German immigrants resided primarily in the north end of the city - often in more substantial brick homes. Drawn largely from the ranks of land-owning farmers, craftsmen, businessmen, and professionals, the Germans usually enjoyed a more

35. Newhall, A Glimpse of Iowa in 1846, 29, 61, 72.

36 U.S. Census, Iowa, 1850; Iowa Census, 1856; Brimeyer and McCormick, Our Early Years, 59, 61; Michael D. Gibson, "Dubuque's Ethnic Roots Run Deep," Julien's Journal, August 1997, 34; Jacobsen, Dubuque, the Key City, 22.

37. Miners' Express, 8/11/1852; Homer L. Calkin, "The Irish in Iowa," Palimpsest 45 (1964), 63-64; Gibson, "Dubuque's Ethnic Roots," 34-36; Jacobsen, Dubuque, the Key City, 22. 
comfortable standard of living than the Irish. Still, the city had its share of unskilled male and female wage earners with German ancestry. ${ }^{38}$

The 1850 county census listed 28 persons with African American heritage; the number in 1856 was only 36. Most Dubuque blacks had migrated from the upper South. Census takers usually identified black men as laborers and black women as servants. But the 1856 census listed individual blacks employed as a painter, a cook, a teamster, a boatman, and a barber. Nearly all of Dubuque's African Americans resided inside the city limits. ${ }^{39}$

While people with German and Irish nationalities figured prominently in the labor force, on Sundays one church dominated the local scene. A large segment of the Dubuque working class embraced Roman Catholicism in religion. Most of the Irish attended Catholic masses as did many Germans. Other residents attended Methodist, Congregational, Presbyterian, Baptist, Lutheran, Episcopalian, or Unitarian churches. An African Baptist Church served the tiny African American community. There were also a few Jews. ${ }^{40}$

In politics, ethnic Germans and Irish filled the ranks of the Democratic Party. The south-end Irish and the north-end Germans provided the major voting blocs that generally kept the Democrats in power. Historian William E. Wilkie claims that the city's Democratic majority "gained strength through the years as the number of Germans in Dubuque steadily increased, mostly because of large families." Those who held elective and appointive political posts at the local level were usually German

38. U.S. Census, Iowa, 1850; Iowa Census, 1856; Gibson, “Dubuque's Ethnic Roots," 35, 36; Jacobsen, Dubuque, the Key City, 22.

39. U.S. Census, Iowa, 1850; Iowa Census, 1856; Hull, Census of Iowa for 1880, 211; Gibson, "Dubuque's Ethnic Roots," 35.

40. U.S. Census, Iowa, Social Statistics, 1850; William J. Petersen, "Beginning of Dubuque: The Web of Life," Palimpsest 21 (1940), 380-81; Conzett, Recollections of People and Events, 18, 186; Childs, History of Dubuque County, 602-3; Wilkie, Dubuque on the Mississippi, 152-56; Gibson, "Dubuque's Ethnic Roots," 35, 36; Oscar Fleishaker, "The Illinois-Iowa Jewish Community on the Banks of the Mississippi River" (Ph.D. diss., Yeshiva University, 1957), 8-9, 12-13, 47, 266; Christopher J. Van Speybroeck, "The Jewish Community of Dubuque, 18331930s," 20-page typescript, Dubuque County Historical Society, Dubuque; Michael J. Bell, "'True Israelites of America': The Story of the Jews of Iowa," Annals of Iowa 53 (1994), 87-89. 
or Irish males who came from the middle and upper ranks of society, self-employed businessmen and professionals. ${ }^{41}$

BEYOND the race, nationality, religion, and political affiliation that shaped their character, Dubuque wage earners held jobs that demanded hard work. Sometimes census takers recorded occupational designations only for the male heads of the household. When noted, the most common job category for women was servant. Others worked in such service occupations as washwoman and seamstress. Male job differentiation occurred along skill lines. Common laborers accounted for the largest single occupational category. Tradesmen included carpenters, shoemakers, blacksmiths, painters, masons, and tailors. With machine technology in its infancy, workers performed laborintensive tasks with hand tools that required manual dexterity and, sometimes, considerable physical strength. ${ }^{42}$

Among the early trades, blacksmithing deserves special attention. Blacksmiths shoed horses, forged iron, and fashioned and repaired all sorts of tools and mechanisms. They occupied a unique position as the pioneer community's most versatile and "most indispensable mechanic." The blacksmith shop, moreover, operated as a gathering place to socialize. The 1850 census listed nine blacksmith establishments, outnumbering any other enterprise and employing two to six workers each. Those who worked in blacksmithing earned average monthly wages of $\$ 22 .{ }^{43}$

In the 1850 industrial census, blank spaces appear in the column for average number of female hands employed. The products of industry schedule in the Dubuque County census for 1850 revealed not only an all-male labor force but also the small scale of manufacturing. The schedule listed those enterprises with an annual product value of $\$ 500$ or more. The employing class, composed primarily of master craftsmen, only hired a few

41. Wilkie, Dubuque on the Mississippi, 221; Oldt, History of Dubuque County, 323-37.

42. U.S. Census, Iowa, 1850; Iowa Census, 1856; Brimeyer and McCormick, Our Early Years, 40; Dubuque City Directory, 1856. See also, Bruce Laurie, Artisans into Workers: Labor in Nineteenth Century America (New York, 1989), 16.

43. George F. Parker, Iowa Pioneer Foundations, 2 vols. (Iowa City, 1940), 1:306-7; U.S. Census, Iowa, Products of Industry, 1850. 
wage earners. With 46 county industries enumerated, a typical establishment averaged slightly fewer than four workers. ${ }^{4}$

Proximity to rich agricultural land made milling an important enterprise. Each of the six flour mills employed three to eight hands and paid wages averaging \$26 per month. Other establishments, all with ten or fewer employees, included leather goods (boots and shoes, harnesses and saddles), meat products, woolen textiles, and metals fabrication. Monthly wages for these jobs averaged $\$ 24 .^{45}$

ECONOMIC ADVANCES brought cheers from the local press, but workplace conditions rarely occasioned comment. Dubuque's growing ranks of wage earners faced harsh working conditions. They usually worked 12 hours per day, 6 days per week, 52 weeks per year. For most this meant manual labor at repetitive tasks. Use of hand tools and physical strength were the chief requirements of most work routines. ${ }^{46}$

Job security remained illusory for many reasons, including weather, business cycles, and new technology. Work-related accidents also played a role: fires, explosions, collisions, and broken tools caused injury and death to workers at lead mines, woodworking shops, grist mills, blacksmith shops, and railroad sites. ${ }^{47}$

Disease also took a heavy toll on Dubuque's working class. In 1850 the leading cause of death was cholera. Other dreaded diseases included smallpox, consumption, scarlet fever, and pneumonia. The 1850 mortality figures reveal that nearly half of the deaths occurred among those two years of age or younger. ${ }^{48}$

44. U.S. Census, Iowa, Products of Industry, 1850. With nearly four workers per manufacturing establishment, Dubuque was slightly above the statewide average of just over three workers per plant. See Hoadley, Industrial Growth of Iowa, 7; and Westburg, "The Classless Society of Pioneer Iowa," 11.

45. U.S. Census, Iowa, Products of Industry, 1850.

46. E. H. Downey, History of Labor Legislation in Iowa (Iowa City, 1910), 1, 7; Brimeyer and McCormick, Our Early Years, 40; Express and Herald, 11/24/1854.

47. Parker, Iowa Pioneer Foundations, 2:212; Haworth, Development of the Woodworking Industry, 31; Brimeyer and McCormick, Our Early Years, 40; Miners' Express, 8/19/1853.

48. U.S. Census, Iowa, Mortality, 1850. See also Oldt, History of Dubuque County, 84, 85, 87, 89, 92, 96, 104; and Conzett, Recollections of People and Events, 197. 
While noting the reality of poverty, early Iowa observer and writer George F. Parker characterized paupers as weak and lazy people with "bad habits and low morals," making them prone to criminality. Parker did, however, recognize "a duty to keep the needy from starvation." The Iowa Code of 1851 compelled the support of paupers by kin or admittance to a poor house, where their labor would go to the highest bidder. The Code of 1851 meant that poor relief was minimal or nonexistent and reflected the fact that "wage-earners and propertyless persons as a class had little or no influence in the creation, interpretation, and administration of this code." Yet a Dubuque County history noted the operation of "several strong organizations for poor relief." The Express and Herald pointedly called for humane help during the winter months when the number of cold and hungry families increased. ${ }^{49}$

The Express and Herald also understood the plight of Dubuque wage earners who received low wages, lived in crowded, poor housing, and struggled to feed and clothe their families. Most workers found themselves living at a subsistence level. Compensation rates reflected skill and gender differences. According to 1850 county statistics, a male day laborer averaged $\$ 1.00$ per day in wages while a carpenter earned $\$ 1.50$. Weekly boarding rates for laboring men amounted to $\$ 1.75$. A female domestic received weekly pay with board of $\$ 1.50 .^{50}$

Adding to the woes of workers, the national consumer price index rose ten points between 1850 and $1855 .{ }^{51}$ Yet, according to the Express and Herald, the 1855 compensation rates for mechanics and laborers remained at roughly the same levels as they had been in $1850 .^{52}$ Alarmed at low wages and rising expenses, the Express and Herald headlined its November 24, 1854, editorial

49. Parker, Iowa Pioneer Foundations, 2:268-73; Westburg, "The Classless Society," 19; Oldt, History of Dubuque County, 114; Express and Herald, 11/29/1855.

50. U.S. Census, Iowa, Social Statistics, 1850.

51. John J. McCusker, How Much Is That in Real Money? A Historical Price Index for Use as a Deflator of Money Values in the Economy of the United States (Worcester, MA, 1992), 328 (reprinted from Proceedings of the American Antiquarian Society 101 [1991)].

52. Express and Herald, 2/24/1855. Local booster G. R. West agreed with the paper on common laborers' pay, but estimated wage rates for mechanics at a much higher level, $\$ 2.00$ to $\$ 3.00$ per day. See West, Statistics, 14 . 
"It Costs Too Much to Live Here." Characterizing bread and meat costs as "too high," the paper claimed that rent was "nearly double what it ought to be." Three months later the paper editorialized that "wages are not high in proportion to what mechanics and laborers have to pay for house rent and the necessaries of life." ${ }^{53}$

Dubuque historian William E. Wilkie noted that downtown Dubuque was characterized by a "great assortment of residence hotels and boarding houses, mostly full of unmarried men." He went on to cite "110 single men" living in a single block. According to the Express and Herald, wage earners coped by crowding "two or more families ... into a space not half large enough for one. ${ }^{\prime 54}$ The working class also bore the heaviest tax burden. While real estate owners paid taxes on "undervalued" property, workers who rented or boarded paid personal property taxes at "full value." ${ }^{55}$

DUBUQUE WORKERS, then, faced low wages and high living costs. While Dubuque's wage earners shared common economic and social interests, they seldom saw themselves as occupying a different social status from their employers. Yet the forces of industrialization brought more and more property-owning employers who operated as capitalists and investors who shaped economic development and determined wage rates. The results, in Dubuque and elsewhere, were an economic system and social priorities set by those with accumulated wealth, leaving workers with the ballot and unions as ways to assert their rights. ${ }^{56}$

Across the country during this period, employers generally regarded labor merely as a commodity and often treated their employees with indifference or disdain. Workers might experience discrimination, abuse, or neglect at the hands of employers who exploited them by demanding long hours in poor working

53. Express and Herald, 11/24/1854, 2/24/1855.

54. Wilkie, Dubuque on the Mississippi, 185; Express and Herald, 2/24/1855.

55. Express and Herald, 2/27/1855.

56. See David Montgomery, Citizen Worker: The Experience of Workers in the United States with Democracy and the Free Market during the Nineteenth Century (New York, 1993), introduction. 
conditions for low pay. ${ }^{57}$ But wage earners began to insist on the dignity, autonomy, and ownership of their labor, not as an exploitable commodity controlled and owned by employers. Slowly, a class consciousness appeared, in the words of historian Sean Wilentz, "as the articulated resistance of wage workers ... to capitalist wage-labor relations." ${ }^{58}$

Historian Walter Licht reminds us that "activist craftsmen formed a distinct segment within working-class communities" and provided "leadership, ideas, and rhetoric for organized labor protest." ${ }^{59}$ In Dubuque some of the city's workers in the mechanical trades turned to defending themselves in a class-based association that expressed their solidarity and initiative. The earliest evidence of a workers' organization comes from 1841 with the founding of the Mechanics' Institute.

The institute's stated purposes included creating "a more social and friendly intercourse among the Mechanics of this place ... to protect their rights and interests" and increasing "our stock of information by debating questions, and having lectures delivered before the Institute." The institute also intended to furnish workers with a suitable library and "to do away with jealousy and party strife, and be united and true to ourselves." In a display of class hostility, the statement of principles castigated "the greater part [of] the trader and the speculator" element as parasitic and "worse than useless in society." Dubuque's mechanics "ought ... to be proud when we find that we are one of the producing class" and realize that "we are, or ought to be, well informed and independent." Finally, the "society" of mechanics would provide a vehicle to "redress our wrongs as well as maintain our rights."

Across the nation, Mechanics' Institutes became prominent in the first half of the nineteenth century. Their emergence reflected the spread of democracy and education among workers.

57. Westburg, "The Classless Society," 35.

58. Sean Wilentz, "Against Exceptionalism: Class Consciousness and the American Labor Movement, 1790-1920," International Labor and Working Class History 26 (Fall 1984), 6. See also Westburg, "The Classless Society," 18, 28, 29; and Scharnau, "Workers, Unions, and Workplaces."

59. Licht, Industrializing America, 71.

60. Miners' Express, 10/23/1841; Oldt, History of Dubuque County, 72. 
The history of Dubuque's institute remains something of a mystery, but it appears that educating its members on issues such as labor relations and slavery became an important focus. One authority holds that Mechanics' Institutes, like the one at Dubuque, declined because of the rise of the cheap press and the growing importance of schools as vehicles for informing wage earners. ${ }^{6}$

Thirteen years after the formation of the Mechanics' Institute, the first bona fide trade union in Dubuque and probably in the state made its appearance. Officially organized on November 4, 1854, the Typographical Union represented "a large majority of the craft." The Typographical Union had become one of the first trade unions organized on a national basis in 1852. The local printers, seeking to protect themselves and their employers from those who fraudulently claimed to be journeymen, issued certificates to qualified traveling journeymen. A more important motivation was to establish "a scale of prices regulating the price of labor." Finally, the local established a registry of strikebreakers, a strike fund, and transfer rights. A committee appointed to contact employers reported that "all" of the "Editors and Proprietors of the city" accepted the wages list. ${ }^{62}$

The local leadership of Andrew Keesecker no doubt helped to account for the initial success of the union. Contemporaries described Keesecker as a strong-minded, reliable, and hardworking man with remarkable knowledge, a retentive memory, and analytical skill. An early resident of the city and a wellknown printer and editorialist, he served as president of the new journeymen printers' organization. Keesecker's long career as an expert printer (he arrived as a pioneer settler in 1833), paralleled the city's early journalistic history. ${ }^{63}$

According to a county history, Keesecker "set the first type in the territory [and] he continued to set type in Dubuque until

61. Clarence Ray Aurner, "Mechanics' Institutions," Iowa Journal of History and Politics 19 (1921), 389, 411, 412-13; Oldt, History of Dubuque County, 81.

62. Express and Herald, 11/6/1854; Northwest, 9/24/1857; Oldt, History of Dubuque County, 104-5; Philip Taft, Organized Labor in American History (New York, 1964), 35-36.

63. Eliphalet Price, "Dubuque in Early Times," Dubuque Herald, 7/13/1865; Dubuque Herald, 4/26/1870, 4/27/1870; Oldt, History of Dubuque County, 105. A Dubuque early settlers list, dated August 6, 1864, is in Special Collections, State Historical Society of Iowa, Iowa City. 
his death in 1870." He assisted the editor and wrote articles for Iowa's first newspaper, the Du Buque Visitor, which initially appeared on May 11, 1836. Keesecker also served as coproprietor of the Miners' Express from its inaugural issue in 1841 until he sold his share of the operation in 1845 . He returned to the newspaper as coproprietor in 1848 and once again sold his interest in 1851. Keesecker then resumed his work as the city's foremost printer and renewed his connection with the Miners' Express in 1853. Following his leadership in founding the Typographical Union, he continued to operate as the union's chief spokesman. Until his death in 1870, Keesecker commanded admiration from his coworkers and respect from the community. ${ }^{64}$

THE FORMATION of the Dubuque Typographical Union represented a new level of workers' organization that emerged against a backdrop of soaring population growth and profound economic change. The period from 1845 to 1855 marked the first stage of the transition from the old pioneer period to the new industrial era. Changes in commerce and manufacturing began to reshape Dubuque's economic landscape. Lead mining and wood products anchored an expanding array of small-scale manufacturing enterprises that included pork packing, brewing, and the production of soap, candles, wagons, and furniture. Pushed by the introduction of new technology, improved transportation, and a rapidly expanding labor force, production soared. Press reports enumerated a pattern of material progress. ${ }^{65}$

Yet the mounting prosperity of Dubuque's economy masked the hardships faced by the working class. Sunrise-to-sunset workdays remained the norm for most jobs. General working conditions remained harsh. Factory production, coming first in the sash-and-door mills, introduced a regimen with closer supervision and a more intense pace of work. Increased work-

64. Oldt, History of Dubuque County, 52, 70, 76, 82, 92, 99; Miners' Express, 10/17/ 1848, 3/5/1851, 4/9/1851, 4/16/1851; Dubuque Herald, 4/26/1870, 4/27/1870, $5 / 9 / 1886$.

65. Miners' Express, 10/12/1854; West, Statistics, 7; Childs, History of Dubuque County, 647-67. A dramatic surge in city improvements occurred between the annual inventory listed in the Miners' Express of 12/19/1849 and the Express and Herald of $1 / 1 / 1856$. 
place mechanization in the form of new saws, beltings, gears, turning shafts, and unguarded machines brought the potential for a higher incidence of accidents and injuries. ${ }^{66}$

A comparison of the wage levels in the mid-1840s and mid1850s reveals stagnation. The annual wages of workers averaged about \$300, essentially unchanged for the decade. Most workers paid high rents for crowded boardinghouses and tenements. They lived a meager existence, only able to maintain a mere subsistence standard of living. Entrepreneurs, on the other hand, enjoyed high profits and luxurious lifestyles. Even during the pioneer period of supposed egalitarian individualism, "class difference, however unconscious, was always apparent." As social and economic life became more and more hierarchical in the 1850s, class lines hardened. ${ }^{67}$

Faced with low wages and poor working conditions, a portion of the city's skilled workmen moved beyond the fraternaloriented Mechanics' Institute and embraced a new kind of solidarity. The journeymen printers organized the Typographical Union and demanded job control in terms of both craft certification and wage levels. These workers thus forged a new labor structure based on workplace issues and subsequently turned to political action, hallmarks of modern trade unionism. In a larger sense, too, the printers drew a clearer distinction between themselves as producers and their employers. But these artisans, like those in other parts of the country, lacked a vision of an inclusive labor movement. They sought to protect the rights and interests of only their members. Trade unions in Dubuque and elsewhere in antebellum America generally excluded women, African Americans, and the unskilled. ${ }^{68}$

The period from 1845 to 1855 , then, brought economic advances, technological innovation, an early form of industrial

66. Johnson, "An Army for Industrialization," 3-4. See also Westburg, "The Classless Society," 18, 27, 28, 29.

67. Parker, Iowa Pioneer Foundations, 2:305 (quote); Johnson, "An Army for Industrialization," 10; Westburg, "The Classless Society," 14, 15, 16, 17, 22, 23, 35. 68. Scharnau, "Workers, Unions, and Workplaces," 56-57. For a close examination of Dubuque labor history in the late nineteenth century, see Ralph Scharnau, "Workers and Politics: The Knights of Labor in Dubuque, Iowa, 1885-1890," Annals of Iowa 48 (1987), 353-77. 
capitalism, and the origins of modern worker-employer relations in Dubuque. Although small-scale industries dominated the city's economy, the number and employee-size of these ventures increased. A fledgling labor movement also made its appearance. The earliest outlines of Dubuque's reputation had emerged by the mid-1850s. Unlike much of the rest of Iowa, Dubuque developed a character forged by its expanding industrialism, its comparatively large working class, and its early experience with trade unionism. ${ }^{69}$

69. Scharnau, "Workers, Unions, and Workplaces." 